\title{
INDUCTION OF MILK IGA ANTIBODIES BY PORCINE RESPIRATORY CORONAVIRUS
}

INFECTION

P. Callebaut, E. Cox, M. Pensaert and K. Van Deun

Laboratory of Virology, Facu1ty of Veterinary Medicine

State University of Gent.

Casinoplein 24, 9000 Gent, Belgium

\section{ABSTRACT}

An ELISA was developed to examine the prevalence of TGEV-specific immunoglobulin ( $\mathrm{Ig}) \mathrm{A}$ in the milk of sows, infected in the field with PRCV or with TGEV. It was shown that previous PRCV-infections can induce the secretion of IgA antibodies in the milk. However, only 9 out of 28 PRCVinfected sows had IgA in their milk whereas 11 TGEV-infected sows all secreted IgA. On farms where a reinfection with PRCV occurred, the number of IgA-secreting sows increased from 2 to 11 on a total of 13 sows. This showed that the presence of IgA antibodies in the milk may depend upon the occurrence of reinfection with PRCV. As demonstrated by density gradient analysis, the milk IgA induced by PRCV was $11 \mathrm{~S}$ secretory $\operatorname{IgA}$ and had the capacity to neutralize TGEV.

\section{INTRODUCTION}

In sow milk the most abundant class of immunoglobulin ( $\mathrm{Ig}$ ) is $\operatorname{IgA}^{1}$. It is mainly produced in the mammary tissue . However, with transmissible gastroenteritis (TGE) as a model, it has been shown that the antigenic stimulation of the IgA secreting cells in the mammary gland ocçurs at a distant mucosal site, i.e. the gut associated 1ymphoid tissues ${ }^{3}$. IgA lymfocytes, stimulated in the gut, subsequently migrate to the mammary gland where they become localized and synthesize IgA antibodies which are secreted in the milk. This mechanism is referred to as the gut-mammary immunologic link. It is considered to be the basis of passive "lactogenic" immunity against enteric infections in suckling piglets, nursing immune sows.

It has been shown that following an infection with respiratory syncytial virus IgA antibodies are secreted in the milk of women ${ }^{4}$. This gives evidence that IgA secretion in the mammary gland may be induced at a mucosal site other than the gut, such as the respiratory tract.

As the porcine respiratory coronavirus (PRCV) primarily replicates in epithelial cells of the respiratory tract ${ }^{5}$, the question arises if a PRCVinfection provokes the secretion of IgA antibodies in the milk of sows. In the present communication an ELISA is described for the detection of IgA antibodies against TGEV/PRCV in sow milk, together with the results of a comparative study of the prevalence of these antibodies in PRCV- and TGEV- 
infected sows. In order to determine some of the properties of the IgA antibodies, milk immunoglobulins were separated by density gradient centrifugation.

\section{MATERIALS AND METHODS}

\section{$\underline{\text { Specimens }}$}

On each of 6 farms between 5 and 8 sows were selected. Milk samples, to be examined for the presence of IgA antibody, were taken at different time intervals between 1 and 4 weeks after farrowing. Serum pairs were collected at the time of farrowing and 4 weeks later.

On 2 of these farms, designated TGEV-A and -B, a TGE outbreak had occurred 2,5 months and 2,5 years, respectively, prior to the time of sampling. The diagnosis of the TGEV-infection had been made by IF staining on gut sections of killed animals at the time of the outbreak. The selection for the present study of individual sows, which had been infected with TGEV on these farms, was based on the demonstration of the presence of differential serum antibodies against TGEV by the competitive inhibition ELISA.

On 4 farms, designated PRCV-A, $-\mathrm{B},-\mathrm{C}$ and $-\mathrm{D}$, an infection with PRCV had occurred prior to the time of sampling. The diagnosis of the PRCVinfection and the selection of individual PRCV-infected sows on these farms was made by demonstrating in serum samples the presence of TGEV neutralizing antibodies and the absence of differential TGEV-antibodies. On farm PRCV-D, the selected sows were experimentally reinfected by oronasal inoculation with $10^{6}$ TCID50 of the Belgian PRCV-isolate TLM $83^{6}$ at 7 days after farrowing.

\section{Contro1 Specimens}

Control TGEV-antibody negative milk samples, used to test the specificity of the IgA ELISA, were collected on 2 farms from 6 and 16 sows, respectively, between 1 and 4 weeks after farrowing.

\section{Collection and Preparation of Milk}

Milk was obtained manually following IM injection of 30 IU of oxytocin. Whole milk was centrifuged at $10000 \mathrm{x} \mathrm{g}$ for $30 \mathrm{~min}$. at $4^{\circ} \mathrm{C}$. The middle fraction was collected and used for the titration fo antibody by VN and IgA ELISA. From samples, to be separated by density gradient centrifugation, casein was removed by pelleting at $85000 \mathrm{x} g$ for $1 \mathrm{~h}$ at $4^{\circ} \mathrm{C}$.

\section{Virus Neutralization (VN) Test}

VN tests with heat inactivated ( $30 \mathrm{~min},{ }_{7}$ at $56^{\circ} \mathrm{C}$ ) serum and milk specimens were performed as described previously ${ }^{7}$, using the Purdue strain of TGEV as the antigen.

\section{Competitive Inhibition ELISA}

The competitive inhibition ELISA for the detection of differential serum antibodies against TGEV, permitting the differentiation of ${ }_{8}$ pigs infected with TGEV or PRCV, was performed as described elsewhere ${ }^{8}$.

\section{Separation of Milk Immunoglobulins}

Milk immunoglobulins were separated by sucrose density gradient centrifugation, performed as described by Vaerman ${ }^{9}$ with minor modifications. 
Briefly, 0,4 m1 milk was layered on top of a 12 to $32,5 \%$ (wt/wt) sucrose gradient in phosphate-buffered saline (PBS), $\mathrm{pH} 7,2$, and centrifuged in a Beckman SW $41 \mathrm{Ti}$ rotor at $200000 \mathrm{x}$ g for $17 \mathrm{~h}$ at $4^{\circ} \mathrm{C}$. After centrifugation $0,5 \mathrm{~m} 1$ fractions were collected and the location of protein peaks was determined by reading the absorbence of the fractions at $280 \mathrm{~nm}$. The fractions were screened by IgA ELISA and tested for the presence of IgA, IgM and IgG by double micro-immunodiffusion utilizing antisera against the Fc fragments of porcine IgA, IgM and IgG (Nordic, Tilburg, The Netherlands). Four fractions, containing predominantly IgA, and 4 fractions with predominantly IgG were pooled, dialyzed overnight against PBS and tested for antibody titer by VN and IgA ELISA. Titers were corrected for the $5 \mathrm{x}$ dilution factor of the immunoglobulins.

\section{TGEV-specific IgA ELISA}

The ELISA was performed in polystyrene microtiter plates (Nunc-Immuno plate Maxisorp F96), using $100 \mu 1$ volumes of reagents per well. Optima1 dilutions of reagents were determined by checkerboard titrations. Plates were coated with a $1 / 10000$ dilution in $0,05 \mathrm{M}$ carbonate buffer, $\mathrm{pH} \mathrm{9,6}$ of a mixture of equal volumes of 2 TGEV-specific monoclonal antibody (MAb) ascites fluids, kindly provided by Dr. L. Enjuanes, Madrid, Spain. The two MAb used have been designated 1DB12 and 6AC3; their preparation and characteristics have been described elsewhere ${ }^{10}$. Following overnight incubation at $37^{\circ} \mathrm{C}$, the plates were washed three times with water containing $0,01 \%$ Tween 80 . A $1 / 50$ dilution of viral antigen in PBS containing $0,01 \%$ Tween 80 and $10 \%$ fetal calf serum (FCS) was added to alternating rows of wells. Diluent without viral antigen was added to the remaining rows, to be used as blanks. The viral antigen was the Purdue strain of TGEV, grown in the swine testicle ST cell line and prepared as described previously. The plates were incubated for $5 \mathrm{~h}$ at $37^{\circ} \mathrm{C}$ and washed 4 times. Two-fold serial dilutions of milk samples (starting at $1 / 5$ ) or sucrose gradient fractions (at a $1 / 5$ dilution) were added each to wells with and without viral antigen and incubated overnight at room temperature. The plates were washed 4 times and a goat anti-swine IgA (Fc)-horseradish peroxidase conjugate, diluted $1 / 2500$, was added to each well for $1 \mathrm{~h}$ at $37^{\circ} \mathrm{C}$. The conjugate was prepared according to the method of Wilson and Nakane ${ }^{11}$, using immunoglobulins, purified from antiserum (Nordic) by conventional methods. Test samples and conjugate were diluted in $0,5 \mathrm{M} \mathrm{NaCl}, \mathrm{pH} \mathrm{7,2,} \mathrm{containing} 0,05 \%$ Tween 80 and $10 \%$ FCS. The plates were washed six times and substrate solution was added, containing $1 \mathrm{mg} / \mathrm{ml}$ 5-aminosalicylic acid-0,005 \% $\mathrm{H}_{2} \mathrm{O} 2$ in $0,01 \mathrm{M}$ sodium phosphate, $1 \mathrm{mM}$ Na2EDTA, pH 6,0. After overnight incubation at $4^{\circ} \mathrm{C}$, the absorbence at $450 \mathrm{~nm}$ was read with a Multiskan (Flow Labs). A sample dilution was scored positive if the absorbence in the well with viral antigen, after subtraction of the absorbence in the blank we11, was $\geqslant 0,050$. The IgA antibody titer was determined as the reciprocal of the highest positive dilution. One IgA antibody-positive milk sample was included in each plate as a control to establish reproducibility.

\section{RESULTS}

\section{Antibody Responses in Serum}

In the serum, taken at the time of farrowing, all the 39 sows from the 6 farms had VN antibody. The geometric mean titer (GMT) was 122 (24-4096). On the farms TGEV-A and TGEV-B the GMT of the VN antibodies increased from 82 at the time of farrowing to 259 four weeks later. As shown in Table 1, 4-fold or higher titer rises were found in the paired sera from some of these sows. Using competitive inhibition ELISA, no significant titer rises of the dif ierential TGEV-antibodies were found; the GMT was 19 (5-160) and 29 (5-160) at the time of farrowing and 4 weeks later, respectively. 
Table 1. VN-antibody responses in serum and milk and IgA antibody responses in milk of sows, previously infected with TGEV or PRCV

\begin{tabular}{|c|c|c|c|c|c|c|c|}
\hline \multirow{3}{*}{$\begin{array}{l}\text { Sow } \\
\text { group ** }\end{array}$} & \multirow[t]{3}{*}{ Sow } & \multicolumn{4}{|c|}{ VN titer } & \multirow{2}{*}{\multicolumn{2}{|c|}{$\begin{array}{l}\text { IgA ELISA } \\
\text { titer in milk }\end{array}$}} \\
\hline & & \multicolumn{2}{|c|}{ Serum } & \multicolumn{2}{|c|}{ Milk } & & \\
\hline & & $0 \mathrm{wpp}^{*}$ & 4 wpp* & 1 wpp* & 4 wpp* & 1 wpp* & 4 wpp* \\
\hline \multirow[t]{5}{*}{ TGEV-A } & 1 & 32 & 256 & 8 & 48 & 160 & 160 \\
\hline & 2 & 64 & 384 & 16 & 48 & 40 & 160 \\
\hline & 3 & 192 & 384 & 12 & 16 & 160 & 160 \\
\hline & 4 & 1536 & 256 & 48 & 48 & 640 & 1280 \\
\hline & 5 & 64 & 96 & 3 & 6 & 80 & 40 \\
\hline \multirow[t]{6}{*}{ TGEV-B } & 1 & 24 & 192 & 12 & 192 & 320 & 1280 \\
\hline & 2 & 24 & 512 & 24 & 96 & 320 & 5120 \\
\hline & 3 & 64 & 192 & 8 & 32 & 80 & 160 \\
\hline & 4 & 192 & 768 & 16 & 32 & 40 & 40 \\
\hline & 5 & 64 & 96 & 48 & 256 & 320 & 640 \\
\hline & 6 & 64 & 256 & 48 & 192 & 640 & 320 \\
\hline \multirow[t]{5}{*}{ PRCV-A } & 1 & 192 & 192 & 6 & 6 & $<5$ & $<5$ \\
\hline & 2 & 4096 & 1024 & 32 & 32 & $<5$ & $<5$ \\
\hline & 3 & 24 & 256 & 32 & 12 & 640 & 2560 \\
\hline & 4 & 96 & 1536 & 8 & 256 & $<5$ & 160 \\
\hline & 5 & 48 & 512 & 12 & 48 & 10 & 160 \\
\hline \multirow[t]{8}{*}{ PRCV-D } & 1 & 96 & 3072 & 2 & 24 & $<5$ & 80 \\
\hline & 2 & 24 & 512 & 2 & 384 & $<5$ & 320 \\
\hline & 3 & 24 & 512 & $<2$ & 64 & $<5$ & 320 \\
\hline & 4 & 48 & 768 & 6 & 96 & $<5$ & 320 \\
\hline & 5 & 96 & 512 & 4 & 96 & $<5$ & 80 \\
\hline & 6 & 64 & 256 & 4 & 96 & $<5$ & 640 \\
\hline & 7 & 64 & 1536 & 3 & 96 & $<5$ & 80 \\
\hline & 8 & 768 & 3072 & 6 & 64 & $<5$ & 320 \\
\hline
\end{tabular}

*wpp $=$ weeks post partum; $* *$ TGEV $-\mathrm{A}=$ infected with TGEV, 2,5 months previously; TGEV-B = infected with TGEV, 2,5 years previously; PRCV-A = infected previously with PRCV; PRCV-D = infected previously with PRCV and experimentally inoculated with PRCV at 1 wpp.

On farms PRCV-A and -D the GMT of the VN-antibodies increased between the time of farrowing and the end of the lactation period from 98 to 728 . Eleven out of the 13 sows showed significant titer rises in the paired sera (Table 1). No VN-titer rises were found in the serum pairs from the sows at farms PRCV-B and -C: the GMT was 198 (48-1024) and 213 (32-1536) at the time of farrowing and 4 weeks later, respectively. All sera, collected on farms PRCV-A to D were negative (titer $<5$ ) in the competitive inhibition ELISA.

VN-antibody Responses in the Milk

The VN-antibody responses in the milk of TGEV- or PRCV-infected sows at different time intervals between 1 and 4 weeks after farrowing are shown in Table 2. The sows from farms TGEV-A and $-B$ had VN-antibodies in all milk samples collected throughout the lactation period. Titers were minimal between 1 and 2 weeks after farrowing and increased towards the end of the lactation period. As indicated in Table 1, some sows showed a 4-fold or higher VN-titer rise between 1 and 4 weeks after farrowing. 
Table 2. Prevalence and titers of VN- and IgA ELISA antibodies in the milk of sows, previously infected with TGEV or PRCV

\begin{tabular}{|c|c|c|c|c|}
\hline \multirow{2}{*}{$\begin{array}{l}\text { Sow group** } \\
\text { (no.) }\end{array}$} & \multirow{2}{*}{$\begin{array}{l}\text { Time of milk } \\
\text { collection } \\
\text { (wpp)* }\end{array}$} & \multirow{2}{*}{$\begin{array}{l}\text { Geometric mean } \\
\text { VN titer (range) }\end{array}$} & \multicolumn{2}{|c|}{ IgA ELISA positive } \\
\hline & & & $\overline{\text { No. }}$ & $\begin{array}{l}\text { Geometric mean } \\
\text { titer (range) }\end{array}$ \\
\hline $\begin{array}{l}\text { TGEV-A } \\
(\mathrm{n}=5)\end{array}$ & $\begin{array}{l}1 \\
2 \\
3 \\
4\end{array}$ & $\begin{array}{l}16(3-48) \\
15(3-48) \\
14(4-32) \\
26(6-48)\end{array}$ & $\begin{array}{l}5 \\
5 \\
5 \\
5\end{array}$ & $\begin{array}{r}240(80-1280) \\
140(40-1280) \\
240(80-640) \\
200(40-1280)\end{array}$ \\
\hline $\begin{array}{l}\text { TGEV-B } \\
(n=6)\end{array}$ & $\begin{array}{l}1 \\
2 \\
3 \\
4\end{array}$ & $\begin{array}{r}27(6-96) \\
21(8-48) \\
63(8-256) \\
99(32-768)\end{array}$ & $\begin{array}{l}6 \\
6 \\
6 \\
6\end{array}$ & $\begin{array}{r}127(20-320) \\
201(40-640) \\
284(40-5120) \\
452(40-5120)\end{array}$ \\
\hline $\begin{array}{l}\text { PRCV-A } \\
(\mathrm{n}=5)\end{array}$ & $\begin{array}{l}1 \\
2 \\
3 \\
4\end{array}$ & $\begin{array}{r}22(12-128) \\
12(6-32) \\
14(3-48) \\
38(6-256)\end{array}$ & $\begin{array}{l}2 \\
2 \\
3 \\
3\end{array}$ & $\begin{array}{r}56(5-640) \\
113(5-1280) \\
80(20-640) \\
402(160-2560)\end{array}$ \\
\hline $\begin{array}{l}\text { PRCV-B } \\
(n=7)\end{array}$ & $\begin{array}{l}1-2 \\
3-4\end{array}$ & $\begin{array}{l}19(6-128) \\
19(6-384)\end{array}$ & $\begin{array}{l}2 \\
2\end{array}$ & $\begin{array}{l}80(40-160) \\
80(20-320)\end{array}$ \\
\hline $\begin{array}{l}\text { PRCV-C } \\
(n=8)\end{array}$ & $\begin{array}{l}1-2 \\
3-4\end{array}$ & $\begin{array}{r}63(12-256) \\
23(6-96)\end{array}$ & $\begin{array}{l}5 \\
5\end{array}$ & $\begin{array}{l}40(5-320) \\
40(5-320)\end{array}$ \\
\hline $\begin{array}{l}\text { PRCV-D } \\
(\mathrm{n}=8)\end{array}$ & $\begin{array}{l}1 \\
3 \\
4\end{array}$ & $\begin{array}{r}3(2-6) * * * * \\
79(4-384) \\
87(24-384)\end{array}$ & $\begin{array}{l}0 \\
8 \\
8\end{array}$ & $\begin{array}{r}<5 \\
160(40-640) \\
207(80-640)\end{array}$ \\
\hline
\end{tabular}

${ }_{\text {Wpp }}=$ weeks post partum; $* *$ TGEV-A $=$ infected with TGEV, 2,5 months previously; TGEV-B = infected with TGEV, 2,5 years previously; PRCV-A, -B, $-C=$ infected previously with PRCV on 3 different farms; PRCV-D = infected previously with PRCV and experimentally inoculated with PRCV at 1 wpp; $* * *$ one negative sow not included.

On the farms with a previous PRCV-infection, all sows except one had VN milk antibodies throughout the lactation period. The latter sow (group PRCV-D) was negative 1 week after farrowing (not included in Table 2). In groups PRCV-A and PRCV-D VN-titers increased at the end of the lactation. As indicated in Table 1,10 out of the 13 sows showed 4-fold or higher titer rises or became positive between 1 and 4 weeks after farrowing. No VN-antibody titer rises were observed in the groups PRCV-B and $-\mathrm{C}$.

\section{IgA Antibody Responses in the Milk}

Twenty two control milk specimens, containing no VN antibody (titer <2), were negative in the IgA ELISA (titer <5).

The antibody responses in the milk of TGEV- or PRCV-infected sows as determined by IgA ELISA are shown in Table 2. All sows from farms TGEV-A and $-B$ had IgA antibodies in the milk throughout the lactation. Titers increased at the end of the lactation period. As indicated in Table 1, some sows in both groups showed a 4-fold or higher titer rise between 1 and 4 weeks after farrowing. 
Table 3. VN- and IgA ELISA antibody titers in milk and in isolated milk IgA and IgG from sows, previously infected with PRCV or TGEV

\begin{tabular}{|c|c|c|c|c|c|c|c|}
\hline Sow group* & Sow & & $i 1 k^{\star *}$ & & $\mathrm{gA}$ & & [gG \\
\hline & no. & $\begin{array}{l}\mathrm{VN} \\
\text { titer }\end{array}$ & $\begin{array}{l}\text { IgA ELISA } \\
\text { titer }\end{array}$ & $\begin{array}{l}\mathrm{VN} \\
\text { titer }\end{array}$ & $\begin{array}{l}\text { IgA ELISA } \\
\text { titer }\end{array}$ & $\begin{array}{l}\mathrm{VN} \\
\text { titer }\end{array}$ & $\begin{array}{l}\text { IgA ELISA } \\
\text { titer }\end{array}$ \\
\hline$\overline{\text { TGEV-A }}$ & 1 & 48 & 160 & 60 & 50 & $<10$ & $<25$ \\
\hline & 2 & 48 & 160 & 15 & 200 & $<10$ & $<25$ \\
\hline TGEV-B & 3 & 256 & 640 & 240 & 400 & 30 & 25 \\
\hline & 4 & 192 & 320 & 120 & 200 & 40 & $<25$ \\
\hline PRCV-A & 5 & 32 & 2560 & 30 & 3200 & 15 & 50 \\
\hline & 6 & 256 & 160 & 160 & 100 & 320 & $<25$ \\
\hline & 7 & 32 & $<5$ & 15 & $<25$ & 80 & $<25$ \\
\hline PRCV-B & 8 & 384 & 320 & 480 & 400 & 20 & $<25$ \\
\hline & 9 & 12 & $<5$ & $<10$ & $<25$ & 20 & $<25$ \\
\hline PRCV-C & 10 & 96 & 320 & 80 & 400 & 10 & $<25$ \\
\hline & 11 & 32 & 320 & 30 & 200 & $<10$ & $<25$ \\
\hline & 12 & 128 & $<5$ & 40 & $<25$ & 120 & $<25$ \\
\hline PRCV-D & 13 & 384 & 320 & 480 & 200 & 40 & $<25$ \\
\hline & 14 & 96 & 640 & 40 & 400 & $<10$ & $<25$ \\
\hline
\end{tabular}

*groups as in Table 2 ; **all milk specimens were collected 4 weeks post partum.

As shown in Table 2, 9 out of the 28 sows were positive in the IgA ELISA 1 week after farrowing on the farms with a previous PRCV infection. The GMT was 50 (5-640). In group PRCV-A, 1 sow became positive 3 weeks after farrowing, whereas two other sows showed 4-fold or higher titer rises between 1 and 4 weeks after farrowing (Table 1 ). Two sows remained negative. In group PRCV-D, the 8 sows became positive 3 weeks after farrowing. The GMT in the 2 groups PRCV-A and $-D$ reached a maximum value of 248 (80-2560) at 4 weeks after farrowing. In the groups PRCV-B and -C, no IgA antibody titer rises were observed. Eight sows from the latter 2 groups were negative during the whole lactation period.

Density Gradient Separation of Milk Immunoglobulins

The results of the separation of immunoglobulins in milk specimens from the different groups of TGEV- and PRCV-infected sows, collected 4 weeks after farrowing, are indicated in Table 3. The IgA ELISA- and VN-activity in milk from 4 TGEV-infected sows was the highest in the isolated IgA. The IgA containing gradient fractions were located in a position between 7S IgG and 19S IgM (not shown). Six out of 7 PRCV-infected sows, containing IgA ELISA reactivity in their milk,gave an identical result. In 1 sow the VNactivity was equally distributed between the isolated IgA and IgG. Three milk samples from PRCV-infected sows, containing VN antibodies but without IgA ELISA reactivity, had the highest VN-titer in the isolated IgG.

\section{DISCUSSION}

From the present results it is clear that previous PRCV-infections can induce the secretion of $\operatorname{IgA}$ antibodies in the milk of sows. These antibodies can be demonstrated using an ELISA for the detection of TGEV-specific 
IgA. The specificity of the test is indicated by the results on control specimens from non-immune sows. Evidence of its isotype-specificity is obtained from the findings with density gradient separated specimens from TGEV- and PRCV-infected sows. Milk samples scored positive by ELISA contain TGEV-specific IgA, as proven by the presence of VN-activity in the isolated IgA. Furthermore, the ELISA reactivity is associated with the isolated IgA. The weak ELISA reactivity found in the isolated IgG from 2 specimens is thought to be due to contamination with IgA resulting from slight overlapping of the IgG and IgA peaks. Milk samples scored negative by ELISA probably do not contain TGEV-specific IgA, since the VN-activity of these samples is mainly associated with the isolated IgG.

The results obtained by density gradient separation further indicate that the IgA secreted by TGEV- and PRCV-infected sows have indistinguishable characteristics. It is çonsidered $11 \mathrm{~S}$ secretory $\operatorname{IgA}$ on the basis of its position in the gradient ${ }^{9}$. Furthermore, the isolated IgA has the capacity to neutralize TGEV. As demonstrated in Table 3, there is no correlation between the VN- and IgA ELISA titer of the IgA, isolated from different sows. This indicates that the proportion of total TGEV-specific IgA, neutralizing the virus, varies depending upon individual differences.

The finding that TGEV-infected sows secrete IgA antibodies in the milk confirms previous reports by others ${ }^{12}$. The results obtained with PRCVinfected sows, showing that not all of them secrete IgA in the milk, cannot be fully explained. As demonstrated by the significant VN-titer rises in the serum of the PRCV-D sows following experimental inoculation with PRCV, a previous infection with PRCV and the presence of serum antibodies do not prevent reinfection with PRCV. Similar VN-titer rises in the serum, without a concomittant rise or appearance of differential TGEV-antibodies, were found in 3 out of 5 remaining sow groups. This demonstrates that in these groups a natural PRCV (re)infection has occurred during the lactation period and that PRCV reinfection may be a frequent event. Reinfection results in the rise or appearance of VN- and IgA-antibodies in the milk. This indicates that in PRCV-infected sows the occurrence of reinfections may determine the prevalence of $\operatorname{IgA}$ in the milk.

The mechanism accounting for the presence of IgA antibodies in the milk following PRCV-infection is not known. On the one hand, PRCV replicates to high titers in the respiratory tract and is likely to stimulate IgA-positive 1 ymfocytes in the bronchi associated 1ymphoid tissue. Therefore, the secretion of IgA in the milk may be an indication for migration of the stimulated cells from the lung to the mammary gland. On the other hand it cannot be excluded that some of the PRCV-antigen reaches the gut associated lymphoid tissue, by ingestion and/or by limited replication in the gut. The secretion of IgA in the milk ${ }_{3}$ would involve then the gut-mammary link, known to be operative in the $\mathrm{pig}^{3}$.

It has been established already that milk IgA, produced following an enteric TGEV-infection, provides protection of suckling piglets against that infection ${ }^{3}$. It is not clear if sows, previously infected with PRCV, protect their suckling piglets against TGEV-infection. So far, contradictory results have been reported ${ }^{3}, 14,15$. As no attention was paid to the IgA content of the sow's milk in these studies, the protective properties against TGE of the milk IgA induced by a previous PRCV infection remain unknown.

Further work is in progress to clarify these points as it may open new ways for vaccination against TGEV. 


\section{ACKNOWLEDGEMENTS}

This work was supported by the Institute for the Encouragement of Scientific Research in Industry and Agriculture (IWONL), Brusse1s, Belgium. The technical assistance of $\mathrm{K}$. De Rudder is gratefully appreciated.

\section{REFERENCES}

1. J. Curtis and F.J. Bourne, Immunoglobulin quantitation in sow serum, colostrum and milk and the serum of young pigs, Biochim. Biophys. Acta 236: 319 (1971).

2. F.J. Bourne and J. Curtis, The transfer of immunoglobulins IgG, IgA and IgM from serum to colostrum and milk in the sow, Immunology $24: 157$ (1973).

3. E.H. Boh1, R.K.P. Gupta, M.V.F. O1quin, and L.J. Saif, Antibody responses in serum, colostrum and milk of swine after infection or vaccination with transmissible gastroenteritis virus, Infect. Immun. 6: 289 (1972).

4. N. Nandapalan, C. Taylor, R. Scott, and G.L. Toms, Mammary immunity in mothers of infants with respiratory syncytial virus infection, J. Med. Virol. 22: 277 (1987).

5. E. Cox, J. Hooyberghs, and M.B. Pensaert, Sites of replication of a porcine respiratory coronavirus related to transmissible gastroenteritis virus in pigs, Res. Vet. Sci. (in press).

6. M. Pensaert, P. Callebaut, and J. Vergote, Isolation of a porcine respiratory, non-enteric coronavirus related to transmissble gastroenteritis, Vet. Q. 8: 257 (1986).

7. M.T. Voets, M. Pensaert, and P.R. Rondhuis, Vaccination of pregnant sows against transmissible gastroenteritis using 2 attenuated virus strains and different inoculation routes, Vet. Q. 2: 211 (1980).

8. P. Callebaut, M.B. Pensaert, and J. Hooyberghs, A competitive inhibition ELISA for the differentiation of serum antibodies from pigs infected with transmissible gastroenteritis virus (TGEV) or with the TGEV-related porcine respiratory coronavirus, Vet. Microbiol. 20: 9 (1989).

9. J.P. Vaerman, "Studies on IgA immunoglobulins in man and animals", Thesis, Louvain (1970).

10. G. Jiménez, J. Correa, M.P. Melgosa, M.J. Bullido, and L. Enjuanes, Critical epitopes in transmissible gastroenteritis virus neutralization, J. Virol. 60: 131 (1986).

11. B. Wilson and P.K. Nakane, Recent developments in the periodate method of conjugating horseradish peroxidase (HRPO) to antibodies, in: "Immunofluorescence and related staining techniques", W. Knapp, K. Holubar and G. Wick, eds., Elsevier/North Holland Biomedical Press, Amsterdam/New York (1978).

12. L.J. Saif, E.H. Bohl, and R.K.P. Gupta, Isolation of porcine immunoglobulins and determination of the immunoglobulin classes of transmissible gastroenteritis viral antibodies, Infect. Immun 6:600 (1972).

13. J. Hooyberghs, M.B. Pensaert, and P. Callebaut, Transmissible gastroenteritis: outbreaks in swine herds previously infected with a TGEVlike porcine respiratory coronavirus, Proc. Int. Pig Vet. Soc. Congress 10: 200 (1988).

14. J.M. Aynaud, P. Have, E. Bottreau, S. Bernard, and J. Szymanski, Natura1 infection of the sows with the porcine respiratory coronavirus (PRCV) induces protective lactogenic immunity against transmissible gastroenteritis (TGE), in: "Résumés réunion mixte des Sociétés Française et Britannique d'Immunologie", Paris (1988).

15. D.J. Paton and I. Brown, Evaluation of porcine respiratory coronavirus induced cross-protection against transmissible gastroenteritis in suckling pigs, Abstr. Congress European Soc. Vet. VIro1. 1: 46 (1989). 